\title{
MÉTODOS POTENCIOMÉTRICOS E MICROCÉLULAS DE CONCENTRAÇ̃̃O
}

\section{Paiva Neto}

O micro-aparelho que o autor procura descrever aqui, destina-se a dosagem potenciométrica de pequenas quantidades (fraçós de $\mu \mathrm{g}$ ) de iônios Cl', Br' e I', em uma solução aquosa.

Naturalmente, o método determina a concentração de iônios ativos, entretanto, como se destina, em geral, a concentrações bastante diluídas, podemos considerar como dosando a concentração total dos iônios referidos acima.

São usados pares de eletrodos de halogenetos de prata $\left(^{*}\right) \mathrm{Ag} / \mathrm{AgHa}$.

O tipo de eletrodo, como mostra a figura 1 , é em forma de solenóide de cêrca de $2 \mathrm{~mm}$ de $\theta$, com mais ou menos 4 a 5 espiras e feito com fio de prata de mais ou menos $0,3 \mathrm{~mm}$ de 0 , recoberto com uma camada de AgHa.

Cada eletrodo segura por capilaridade uma gôta de solução, ou mesmo uma micro-gôta. Usando dois eletrodos iguais, em um é colocada uma gôta da solução padrão e no outro uma gôta de solução problema. As duas gotas ou micro-gotas são ligadas por meio de uma ponte formada com um capilar de cêrca de $0,1 \mathrm{~mm}$ de $\theta$ interno, e cheio com uma solução de $\mathrm{KNO}_{3} \mathrm{~N} / 1000$ e isento de halogênios, sulfetos, tiocianetos e férrocianetos. Considerando uma micro-gôta igual a $1 / 3$ de gôta ou seja $1 / 60 \mathrm{de}^{3}$, podemos fàcilmente dosar $0,01 \mu \mathrm{g}$ de $\mathrm{Cl}^{\prime}$.

A diferença de potencial que se origina entre essas duas semi-células de concentração é regida pela fórmula de Nernst, ou seja

$$
\mathrm{E}=\frac{\mathrm{R} T}{\mathrm{n} F} \ln \frac{\mathrm{C}_{2}}{\mathrm{C}_{1}}
$$

$\mathbf{C}_{2}=$ concentração conhecida

$\mathrm{C}_{1}=$ concentração problema

(*) $\mathrm{Ha}=$ Halogeneto $-\mathrm{Cl} ; \mathrm{Br}$; ou $\mathrm{I}$. 
Resumindo e passando a fórmula para log de Briggs, temos

$$
\frac{\mathrm{E}}{0,059}=\log \frac{\mathrm{C}_{2}}{\mathrm{C}_{1}}
$$

donde fàcilmente podemos tirar o valor de $C_{1}$, ou seja concentração mol/litro de $\mathrm{Ha}^{\prime}$ da solução problema. 
Instituto Agronômico

Seç̧ão de Agrogeologia

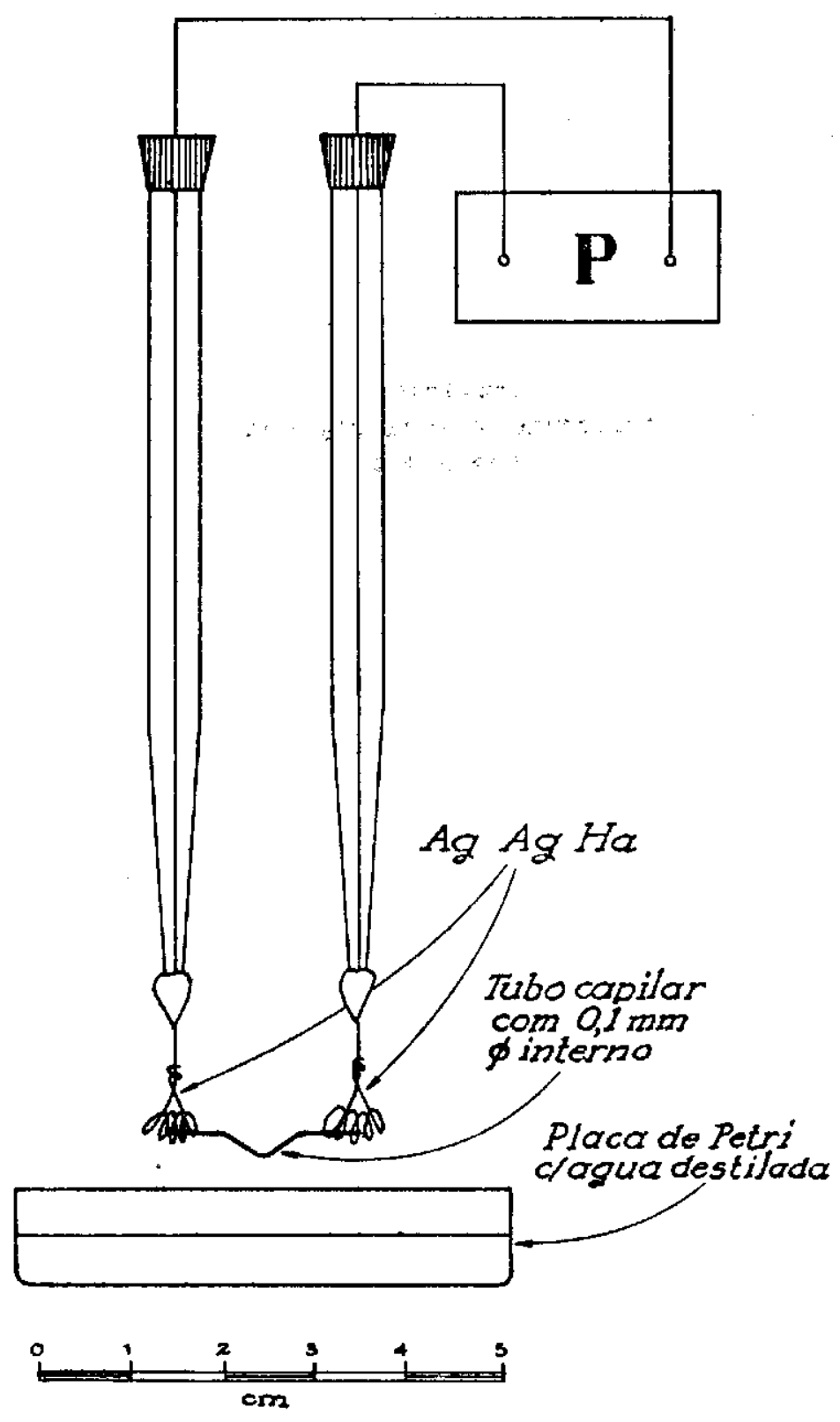

